\title{
PENERAPAN MODEL COOPERATIVE INTEGRATED READING AND COMPOSITION DALAM PEMBELAJARAN KETERAMPILAN MEMBACA PEMAHAMAN
}

\author{
Budi Febriyanto ${ }^{1}$ ) \\ budi_febry88@yahoo.co.id
}

\begin{abstract}
ABSTRAK
Penelitian ini dilatarbelakangi oleh masalah keterampilan membaca pemahamansiswa yang rendah. Penelitian ini bertujuan untuk menguji perbedaanketerampilan membaca pemahaman siswa sekolah dasar antara kelas eksperimen yang menerapkan model pembelajaranCooperative Integrated Reading and Composition dengan kelas kontrol yang menerapkan pembelajaran konvensional. Dalam penelitian ini digunakan pendekatan kuantitatif dengan metode kuasieksperimen. Desain penelitian menggunakan Nonequivalent Control Groups Design (NCGD). Sampel penelitian adalah siswa SDN Sukapura kelas VA sebanyak 30 siswa sebagai kelas eksperimen dan siswa SDN Sukapura kelas VB sebanyak 30 siswa sebagai kelas kontrol. Alat pengumpul data berupa lembar soal membaca pemahaman. Teknik pengumpulan data berupa tes yaitu prates untuk mengukur kemampuan awalketerampilan membaca pemahaman dan pascates untuk melihat kemampuan akhir keterampilan membaca pemahaman. Berdasarkan hasil penelitian diperoleh kesimpulan yaitu terdapat perbedaan peningkatanketerampilan membaca pemahaman antara siswa yang memperoleh pembelajaran menggunakan model CIRC pada kelas eksperimendengan siswa yang memperoleh pembelajaran konvensional pada kelas kontrol sehingga siswa pada kelas eksperimen lebih baikdalam memahami isi cerita suatu wacana.Artinya siswamemiliki keterampilan membaca pemahaman lebih baik dengan diajarkan melalui model CIRC, karena dengan CIRC siswa dituntut untukbekerja sama dengan teman kelompoknya untuk memahami isi bacaan suatu wacana serta menuliskan kembali isi cerita tersebutsebab dalam CIRCterdapat keterpaduan antara membaca dan menulis secara kooperatif.
\end{abstract}

Kata Kunci: cooperative learning, cooperative integrated reading and composition, dan keterampilan membaca pemahaman.

\footnotetext{
$\overline{1}$ Penulis adalah dosen tetap Prodi PGSD Fakultas Pendidikan Dasar dan Menengah Universitas Majalengka
} 


\section{Pendahuluan}

Bahasa memiliki peranan yang penting dalam perkembangan intelektual, sosial, dan emosional siswa serta menunjang keberhasilan mempelajari semua bidang studi.Badan Standar Nasional Pendidikan (BSNP) mengemukakan bahwa tujuan pembelajaran bahasa Indonesia ialah untuk meningkatkan kemampuan siswa dalam berkomunikasi dengan bahasa Indonesia yang baik dan benar, baik secara lisan maupun tertulis serta menumbuhkan apresiasi terhadap hasil karya kesastraan manusia Indonesia.

Bahasa Indonesia memiliki peran yang sangat penting dan merupakan penunjang untuk mempelajari mata pelajaran atau bidang lain. Pembelajaran membaca pemahaman di SD melalui mata pelajaran bahasa Indonesia yaitu pentingnya membaca untuk menggali informasi harus disertai dengan keterampilan membaca yang baik sehingga membaca menjadi efektif bagi siswa. Dengan demikian, membaca yang perlu dijadikan perhatian adalah hal-hal penting berkenaan dengan informasi yang terdapat dalam bacaan yang dibacanya sebab tidak semua kata dalam bacaan merupakan hal penting yang harus diingat dan dipahami.Keterampilan membaca tidak dapat dipisahkan dari pemahaman terhadap bacaan sehingga apa yang dibaca harus bermakna. Keterampilan pemahaman terhadap bacaan tersebut perlu diketahui dan dipahami sehingga dapat semakin meningkatkan kemampuan membacasiswa.

Meskipun membaca merupakan hal yang sangat esensial dalam kehidupan modern, tetapi kondisi di lapangan menunjukkan hal lain. Hal tersebut di dukung penilaian yang dilakukan olehProgramme for International Student Assessment (PISA) yang menunjukkan bahwa Negara Indonesia merupakan negara dengan tingkat kemampuan membaca yang rendah. "Kemampuan membaca pemahaman hasil penilaian PISA tahun 2009 terhadap siswa Indonesia menunjukkan hasil berkategori rendah yaitu sebesar 402. Kondisi ini menempatkan Indonesia pada peringkat ke-57 dari 65 negara yang dinilai”(OECD, 2010, hlm. 56). Penelitian terhadap kemampuan membaca pemahaman juga dilakukan oleh Progress in International Reading Literacy Study (PIRLS) adalah studi literasi membaca yang dirancang untuk mengetahui kemampuan siswa sekolah dasar dalam memahami bermacam ragam bacaan. Penelitian yang dilakukan oleh PIRLS pada tahun 2011 terhadap kemampuan membaca siswa sekolah dasar menunjukkan hal yang sama yakni Indonesia merupakan Negara dengan tingkat kemampuan membaca yang rendah yaitu menempati urutan 43 dari 46 negara. Berdasarkan data PIRLS diperoleh informasi bahwa skor kemampuan membaca siswa Indonesia hanya mencapai 428 dan masih dibawah rerata internasional PIRLS scale centerpoint yang mencapai 500.

Hal yang menjadi fokus permasalahanadalah masih rendahnya keterampilan membaca pemahaman siswa. Berdasarkan kenyataan tersebut, perlu kiranya merancang kegiatan pembelajaran dalam bentuk penggunaan suatu model pembelajaran yang berpusat pada siswa dengan menekankan pada kegiatan bekerja dalam kelompok dan terdapat kegiatan yang menyenangkan bagi siswa di dalamnya.Berbagai pendekatan, model, metode dan teknik pembelajaran telah peneliti analisis serta membaca referensi hasil dari penelitian para peneliti yang lain. Telah banyak tindakan yang diterapkan untuk mengembangkan keterampilan membaca pemahaman. Hasil dari telaah tersebut memutuskan untuk menggunakan model pembelajaran Coopetative Integrated Reading and Composition (CIRC) dalam pembelajaran bahasa Indonesia karena model CIRC 
dianggap dapat menjadi solusi dalam menyikapipermasalahan tersebut.

\section{Keterampilan Membaca}

Crawley dan Mountain (dalam Rahim, 2005, hlm. 3) menyatakan bahwa 'membaca merupakan gabungan proses perseptual dan kognitif. Membaca sebagai proses visual merupakan proses menerjemahkan simbol tulis ke dalam bunyi.'Selain itu, Heilman (dalam Resmini, Churiyah dan Sundori, 2006, hlm. 1) menyatakan bahwa 'Membaca (reading) adalah kegiatan berinteraksi dengan bahasa yang dikodekan ke dalam cetakan (huruf-huruf)'.Dengan demikian dapat disimpulkan bahwa membaca adalah kegiatan menerjemahkan simbol-simbol tulis kedalam bentuk bunyi yang memiliki makna.

"Tujuan utama dalam membaca adalah untuk mencari serta memperoleh informasi, mencakup isi, memahami makna bacaan" (Tarigan, 2013, hlm. 9).Anderson (dalam Linse, 2005, hlm. 71) menyatakan bahwa 'tujuan membacaadalah reading for information (membaca untuk mendapatkan informasi), reading for pleasure (membaca untuk kesenangan) dan reading for comprehension (membaca

pemahaman)'.Terkait beberapa tujuan membaca di atas, dapat disimpulkan bahwa tujuan membaca adalah memperoleh sumber-sumber informasi berupa pengetahuan yang dapat dimanfaatkan secara produktif (menghasilkan sesuatu) dan memperoleh kesenangan (hiburan).

Terdapat beberapa jenis kegiatan yang dapat dilakukan oleh guru dalam kegiatan reading/membaca yaitu:Reading Aloud, Silent Reading, Reading Comprehensiondan Independent Reading.

\section{Membaca Pemahaman}

Salah satu standar membacadalam Standar Kompetensi Lulusan Satuan Pendidikan adalah memahami makna dari teks bacaan. Memahami teks bacaan merupakan salah satu jenis dan tujuan di dalam membaca, yaitu membaca pemahaman.

Menurut Tarigan (2013, hlm. 58) "membaca pemahaman adalah jenis membaca untuk memahami standarstandar atau norma kesastraan (literary standards), resensi kritis (critical review), drama tulis (printed drama) dan pola-pola fiksi (patterns of fiction) dalam usaha memperoleh pemahaman terhadap teks dengan menggunakan strategi tertentu." Membaca pemahaman dapat pula diartikan sebagai serangkaian proses yang dilakukan pembaca untuk menemukan informasi dan memahami informasi yang terkandung dalam sebuah teks bacaan.

Membaca pemahamanbertujuan agar siswa mampu memahami teks bacaan yang dipelajari, mampu menemukan informasi dan makna dalam bacaan, serta mampu menjawab pertanyaan yang berkaitan dengan teks bacaan tersebut. Berdasarkan tujuan tersebut, terdapat beberapa indikasi pemahaman yang perlu diperhatikan di dalam menentukan ketercapaian tujuan pembelajaran.Brown (dalam Abidin, 2010, hlm. 128) memaparkan beberapa indikasi membaca pemahaman yang harus tercapai tersebut sebagai berikut.

a. Melakukan, pembaca memberikan respons secara fisik terhadap perintah membaca.

b. Memilih, pembaca memilih alternatif bukti pemahaman baik secara lisan atau tulisan.

c. Mengalihkan, pembaca mampu menyampaikan secara lisan apa yang telah dibacanya.

d. Menjawab, pembaca mampu menjawab pertanyaan tentang isi bacaan.

e. Mempertimbangkan, pembaca mampu menggarisbawahi atau mencatat pesanpesan penting yang terkandung dalam bacaan.

f. Memperluas, pembaca mampu memperluas bacaan atau minimalnya 
mampu menyusun bagian akhir cerita (khusus untuk bacaan fiksi).

g. Menduplikasi, pembaca mampu membuat wacana serupa dengan wacana yang dibacanya (menulis cerita berdasarkan versi pembaca).

h. Modeling, pembaca mampu memainperankan cerita yang dibacanya.

i. Mengubah, pembaca mampu mengubah wacana ke dalam bentuk wacana lain yang mengindikasikan adanya pemrosesan informasi.

Kesembilan point tersebut merupakan indikasi di dalam menentukan ketercapaian tujuan membaca pemahaman. Ketercapaian tujuan di dalam membaca pemahaman akan dikatakan berhasil apabila salah satu atau lebih dari kesembilan indikasi tersebut dapat dicapai oleh siswa.

\section{Taksonomi dalam Tes Membaca}

Ada dua jenis taksonomi yang dapat digunakan dalam tes membaca, yaitu taksonomi Bloom dan taksonomi Barret (Resmini, 2006, hlm.170-173) adalah sebagai berikut.

a. Taksonomi Bloom

Bloom membedakan adanya 3 ranah (domain), yaitu kognitif, psikomotor, dan afektif. Ranah kognitif dibedakan menjadi 6 tingkatan, yaitu: ingatan, pemahaman, penerapan, analisis, sintesis, dan evaluasi.

b. Taksonomi Barret membedakan adanya 5 kelompok intelektual dalam kegiatan membaca pemahaman, yaitu:

1) Pemahaman literal, yakni kemampuan mengenal sesuatu atau fakta atau mengingat kembali sesuatu atau fakta.

2) Penataan kembali (reorganization), yakni kemampuan menganalisis, mensintesis, menata ide-ide dan informasi yang diungkapkan dalam bacaan.

3) Pemahaman inferensial, yakni kemampuan untuk menggunakan idea tau informasi yang secara eksplisit tertuang dalam bacaan beserta dengan intuisi dan pengalaman pribadi yang dimilikinya sebagai dasar untuk memecahkan persoalan.

4) Pemahaman evaluatif, yakni kemampuan untuk memastikan dan menilai kualitas, ketelitian, kebergunaan atau kebermanfaatan ide yang terdapat dalam wacana.

5) Apresiasi, yakni kemampuan untuk menerapkan kepekaan emosional dan estetika yang dimilikinya dalam merespon bentuk, gaya, struktur, serta teknik pemaparan ide dalam bacaan.

\section{Hakekat Pembelajaran Kooperatif}

CIRC merupakan salah satu tipe pembelajaran kooperatif yang termasuk pula kedalam pembelajaran terpadu membaca dan menulis. Cooperative learning atau pembelajaran kooperatif adalah salah satu bentuk pembelajaran yang berdasarkan pada kegiatan kerjasama, sejumlah siswa sebagai anggota kelompok menyelesaikan tugas kelompoknya secara bersama dan saling membantu satu samalain untuk memahami suatu materi pelajaran.

Menurut Slavin (2005, hlm. 8) dalam metode pembelajaran kooperatif, para siswaduduk bersama dalam kelompok yang beranggotakan empat orang untuk menguasai materi yang disampaikan oleh guru. Sejalan dengan hal tersebut Abidin (2014, hlm. 241) mengatakan bahwa pembelajaran kooperatif merupakan sistem pembelajaran yang memberikan kesempatan kepada anak didik untuk bekerjasama dengan sesama siswa dalam tugas-tugas terstruktur. Dengan demikian pembelajaran kooperatif dikenal dengan pembelajaran secara berkelompok, tetapi dalam pembelajaran kooperatif anak didik tidak hanya belajar kelompok atau kerja kelompok karena dalam kooperatif ada dorongan antar sesama anggota kelompok 
untuk dapat menyelesaikan tugas dan mencapai keberhasilan belajar secara bersama berdasarkan kemampuan dirinya dan andil dari anggota kelompoknya dan kelompok lain selama pembelajaran.

Di dalam pelaksanaannya, model cooperative learning membutuhkan partisipasi dan kerjasama dalam kelompok belajar. Model cooperative learning ini bermanfaat bagi siswa dengan tujuan siswa dapat belajar secara berkelompok bersama teman-temannya dengan cara saling menghargai pendapat dan memberikan kesempatan kepada orang lain untuk mengemukakan pendapatnya.

Dengan demikian, pembelajaran kooperatif memberikan kesempatan kepada siswa untuk meningkatkan kemampuannya baik secara akademik maupun secara sosial.Menurut Lie (2010, hlm. 38-39) dalam pengelolaan kelas pembelajaran kooperatif, harus memperhatikan tiga hal penting, yakni "pengelompokkan, semangat cooperative learning, dan penataan ruang kelas". Pengelompokkan kemacamragaman (heterogenitas) merupakan ciri-ciri yang cukup menonjol dalam pembelajaran kooperatif. Kelompok heterogenitas dapat dibentuk dengan memperhatikan berbagai macam aspek diantaranya, keanekaragaman gender, latar belakang agama sosio-ekonomi dan etnik, serta kemampuan akademis. Dalam hal kemampuan akademis, dalam kelompok kooperatif biasanya terdiri dari satu orang berkemampuan tinggi, dua orang dengan kemampuan akademis sedang atau cukup dan yang lainnya dari kelompok kemampuan akademi kurang.

Dalam penerapan pembelajaran kooperatif terdapat berbagai macam teknik yang bisa digunakan untuk melaksanakan pembelajaran kooperatif, diantaranya adalah makeamatch (mencari pasangan), bertukar pasanngan, berpikir berpasangan (TPS), berkirim salam dan soal, kepala bernomor (NHT), two stay two stray, inside-outside circle, jigsaw, paired storytelling, teams game tournament (TGT), students achievement division (STAD) dan cooperative integrated reading composition (CIRC). Dalam penelitian ini penulis menggunakan model CIRC, dalam pembelajarannya terdapat kegiatan membaca dan menulis secara terpadu.

\section{Cooperative Integrated Reading and Composition}

Pembelajaran kooperatif tipe CIRC dari segi bahasa dapat diartikan sebagai suatu model pembelajaran kooperatif yang mengintegrasikan suatu bacaan secara menyeluruh,

kemudian mengomposisikannya menjadi bagianbagian yang penting (Hosnan, 2014, hlm. 259). Pembelajaran CIRC dapat membantu siswa mengembangkan keterampilan membaca pemahaman dan menulis secara terpadu sehingga siswa dapat memahami informasi yang berasal dari bahan bacaan dan mengkomunikasikannya secara tertulis dari hasil pemahamannya tersebut. Model pembelajaran CIRC merupakan salah satu bagian dari cooperative learning yang mudah diterapkan, melibatkan aktivitas seluruh siswa tanpa harus ada perbedaan status, melibatkan peran siswa sebagai tutor sebaya.

Hiebert, 1983 (dalam Slavin, 2010, hlm. 201) menjelaskan, sebuah fitur yang bersifat hampir selalu universal dari pengajaran membaca adalah penggunaan kelompok membaca yang terdiri atas para siswa dengan tingkat kinerja yang sama. Dasar pemikiran utama untuk pelajaran membaca adalah bahwa para siswa perlu memiliki materi-materi yang sesuai dengan tingkat kemampuan mereka. Selanjutnya Slavin menjelaskan satu fokus utama dari kegiatan CIRC sebagai cerita dasar adalah membuat penggunaan waktu tindak lanjut menjadi lebih efektif: Para siswa yang bekerja yang bekerja di dalam tim-tim kooperatif dari kegiatan-kegiatan ini, yang dikoordinasikan dengan pengajaran kelompok membaca, supaya 
dapat memenuhi tujuan dalam bidangbidang lain seperti pemahaman membaca, kosakata, pembacaan pesan, dan ejaan. Para siswa termotivasi untuk saling bekerja satu sama lain dalam kegiatankegiatan ini atau rekognisi lainnya yang didasarkan pada pembelajaran seluruh anggota tim.

Slavin (2010, hlm. 204) mengemukakan tujuan utama dari para pengembangprogram CIRC terhadap pelajaran menulisdan seni berbahasa adalah untuk merancang,mengimplementasikan, dan mengevaluasipendekatan proses menulis pada pelajaranmenulis dan seni berbahasa yang akanbanyak memanfaatkan kehadiran teman satukelas. Respon dari kelompok teman adalahunsur khas dari model-model prosespenulisan, tetapi keterlibatan teman jarangsekali menjadikan kegiatan sentralnya. Akantetapi, dalam program CIRC, para siswamerencanakan, merevisi, dan menyuntingkarangan mereka dengan kolaborasi yangerat dengan teman satu tim mereka.Pengajaran mekanika bahasa benar-benarterintegrasi sekaligus menjadi bagian daripelajaran menulis, dan pelajaran menulissendiri terintegrasi dengan pengajaranpelajaran memahami bacaan baik denganketerpaduan kegiatankegiatan prosesmenulis dalam program membaca maupundengan penggunaan kemampuan memahamibacaan yang baru dipelajari dalampengajaran pelajaran menulis.

Slavin (2010, hlm. 205) mengemukakan unsur utama CIRC sebagai berikut.

a. Kelompok Membaca

Siswa di bagi dalam kelompokkelompok yang terdiri dari dua atau tiga orang. Kelompok ini dibagi secara heterogen, menurut tingkatan kemampuan siswa yang dapat ditentukan oleh guru.

b. Tim
Siswa dibagi dalam pasangan atau trio, kemudian pasangan-pasangan itu dibagi kedalam tim yang terdiri dari pasangan atau trio dua kelompok membaca atau tingkat.

c. Kegiatan-kegiatan yang Berhubungan dengan Cerita

Para siswa menggunakan bahan bacaan dasar. Cerita diperkenalkan dan didiskusikan dalam kelompok membaca yang diarahkan guru. Dalam kelompok guru menentukan tujuan dari membaca, memperkenalkan kosakata baru, mengulang kosakata lama, mendiskusikan cerita setelah para siswa selesai membacanya, dan sebagainya. Diskusi tentang cerita disusun untuk menekankan kemampuan-kemampuan tertentu seperti membuat dan mendukung prediksi dan mengidentifikasikan masalah dalam bentuk narasi.

Staven (dalam Huda, 2010, hlm. 126) mengemukakan "Dalam CIRC, siswa ditempatkan dalam kelompok-kelompok kecil, baik homogen maupun heterogen. Pertama-tama, mereka mengikuti serangkaian instruksi guru tentang keterampilan membaca dan menulis, kemudian praktik, lalu pra penilaian, dan kuis. Setiap kelompok tidak bisa mengikuti kuis hingga anggota-anggota di dalamnya benar-benar siap."

Dapat disimpulkan bahwa pembelajaran kooperatif tipe CIRC ini dapat membangun pengetahuan siswa, dalam pembelajaran ini siswa bekerja dalam kelompoknya. Mereka bekerjasama dalam kelompok untuk melakukan tugastugas yang diberikan guru. Dalam kelompok mereka juga saling membantu, yakni anggota kelompok yang pandai dapat membantu angggota kelompok yang masih lemah sehingga dalam pembelajaran kooperatif tipe CIRC ini terdapat kontribusi positif dari anggota kelompok.

Diharapkan dengan pembelajaran kooperatif tipe CIRC ini dapat lebih 
efektif untuk meningkatkan kemampuan siswa untuk memahami bacaan. Pembelajaran kooperatif tipe CIRC terbukti efektif jika rata-rata hasil tes pemahaman bacaan kelompok eksperimen lebih tinggi dibandingkan kelompok kontrol.

Secara khusus, Slavin (dalam Sharan, 2014, hlm. 39) mengemukakan bahwa berdasarkan hasil penelitian CIRC memberikan pengaruh yang positif bagi siswa yang memiliki hambatan akademis dan memberikan bukti bahwa metode ini sama-sama efektif untuk siswa yang pintar.

\section{Metode Penelitian}

Penelitian ini merupakan penelitian kuantitatif dengan metode kuasieksperimen atau eksperimen semu.Menurut Ruseffendi (2006, hlm. 52) penelitian kuasieksperimen merupakan penelitian eksperimen semu dimana subjek penelitian tidak dikelompokkan secara acak, tetapi menerima keadaan subjek apa adanya.Penelitian

kuasieksperimendigunakan untuk mencari perbedaan keterampilan membaca pemahaman siswa antara kelas yang menerapkan model CIRC dengan kelas yang menerapkan pembelajaran konvensional.

Bentuk desain penelitian yang digunakan adalah desain kelompok kontrol non ekuivalen. Desain ini merupakan bagian dari bentuk kuasi eksperimen dengan jumlah kelas yang digunakan sebanyak dua kelas yaitu kelas eksperimen dan kelas kontrol. Penelitian ini terdiri dari variabel bebas dan variabel terikat. Variabel bebasnya adalah model pembelajaran CIRC dan pembelajaran konvensional. Variabel terikatnya yaitu keterampilan membaca. Pemberian pembelajaran model CIRC pada kelas eksperimen dan pembelajaran konvensional pada kelas kontrol sehingga desain yang digunakan dalam penelitian adalah kuasiekperimen yang dapat digambarkan pada tabel berikut.

\begin{tabular}{|l|l|l|l|}
\hline Kelompok & Pratest & Perlakuan & Pascatest \\
\hline Eksperimen & $\mathrm{O}_{1}$ & $\mathrm{X}$ & $\mathrm{O}_{2}$ \\
\hline Kontrol & $\mathrm{O}_{3}$ & - & $\mathrm{O}_{4}$ \\
\hline
\end{tabular}

Langkah-langkah penelitian metode eksperimen kuasi bentuknonequivalent groups pratest-posttets designakan dilaksanakan dengan langkah-langkah sebagai berikut:

1. Sebagai langkah awal, peneliti melakukan observasi awal terhadap sekolah yang akan dijadikan lokasi penelitian.

2. Secara purposif memilih dua sampel yang tersedia, sampel yang terpilih masing-masing menjadi kelompok yang mendapatkan pembelajaran CIRC dankelompok yang memperoleh pembelajaran konvensional.

3. Memberi pelatihan kepada guru mengenai pembelajaranCIRCdan membuat kesepakatan bahwa pembelajaran dilaksanakan oleh guru bersangkutan. Peneliti sebagai observer dan partner guru. Pembelajaran disesuaikan dengan jadwal yang telah direncanakan.

4. Memberi prates masing-masing kelompok.

5. Memberikan perlakuan terhadap tiaptiap kelompok. Kelompok yang mendapatkan pembelajaran CIRCdan kelompok yang memperoleh pembelajaran konvensional Masingmasing kelompok diberi pascates sesuai dengan variabel terikat.

6. Mengumpulkan data dan selanjutnya mengolah data

7. Menganalisis data

8. Menarik kesimpulan dari hasil penelitian.

\section{Populasi dan Sampel Penelitian}

Populasi dalam penelitian ini adalah seluruh siswa kelas V SDNSukapura pada tahun ajaran 2014/2015sedangkan siswa kelas $\mathrm{V}$ yang menjadi subjek penelitian 
berjumlah 60 orang. Sampel penelitian dilakukan terhadap dua kelas yang mempunyai karakteristik yang sama. Penentuan sampel penelitian berdasarkan purposive sampling dengan maksud agar penelitian dapat berjalan secara efektif dan efisien terutama dalam hal pengawasan, kondisi subyek penelitian, waktu penelitian yang ditetapkan, kondisi tempat penelitian serta prosedur perizinan. Berdasarkan teknik tersebut diperoleh siswa kelas VA SD Negeri Sukapura sebagai kelas eksperimen sebanyak 30 siswa dan siswa kelas VB SD Negeri Sukapura sebagai kelas kontrol sebanyak 30 siswa.

\section{Instrumen Penelitian}

Untuk memperoleh data yang akurat dalam penelitian, diperlukan alat pengumpulan data yang tepat dengan permasalahan pada penelitian ini, yaitu sebagai berikut:

\section{a. Lembar Soal}

Soal yang digunakan yaitu soal isiandigunakan untuk mengukur keterampilan membaca pemahaman. Tes keterampilan membaca digunakan untuk mengukur kompetensi siswa memahami isi informasi yang terdapat dalam bacaan berupa wacana. Secara umum wacana atau bahan bacaan disesuaikan dengan perkembangan siswa. Pemilihan bahan bacaan juga mempertimbangkan dari segi tingkat kesulitan, panjang pendek isi, dan jenis atau bentuk bahan bacaan.

b. Lembar Observasi

Lembar observasi ini digunakan untuk melihat kegiatan pembelajaran dengan menggunakanmodel pembelajaran CIRC. Lembar observasi ini dapat mengamati apakah pembelajaran sudah sesuai dengan tahapan pembelajaran dengan model pembelajaran CIRC.

\section{Analisis Data}

Data yang dihasilkan dari penelitian ini berupa data kuantitatif, data tersebut berasal dari data hasil belajar siswa pada kelas eksperimen dan kelas kontrol. Pada penelitian ini teknik analisis data yang digunakan menggunakan bantuan software komputer yaitu SPSS versi 21 dengan pendekatan statistik sebagai berikut:

Uji normalitas digunakan untuk mengetahui kondisi data apakah berdistribusi normal atau tidak. Sebab untuk menguji hipotesis menggunakan statistik parametrik syaratnya adalah data harus berdistribusi normal. Dengan data berdistribusi normal maka menggunakan uji liliefors (Kolmogorov-Smirnov). Dengan kriteria pengujiannya adalah jika nilai Signifikasi (Sig) atau nilai probabilitas > 0.05 maka distribusi adalah normal, sedangkan jika nilai Signifikasi (Sig) atau nilai probabilitas $<0.05$ maka distribusi adalah tidak normal.

Uji homogenitas dilakukan dengan tujuan melihat kesamaan beberapa bagiansampel atau seragam tidaknya varian sampel-sampel yaitu apakah mereka berasaldari populasi yang sama.

Uji beda (uji-t) dilakukan guna membuktikan hipotesis mengenai adanya perbedaan penerapan model pembelajaran CIRC terhadap keterampilan membaca pemahaman siswa dalam pembelajaran bahasa Indonesia.

Data prates dan pascates yang telah diperoleh dalam penelitian ini selanjutnya di uji normalitas dan homogenitasnya. Apabila data tersebut normal dan homogen maka menggunakan uji parametrik yaitu uji t. Bagi data yang normal tapi tidak homogen maka menggunakan uji t'. Sedangkan data yang tidak normal dan homogen menggunakan uji non parametric yaitu uji Mann Whitney.

\section{Hasil Penelitian dan Pembahasan}
A. Deskripsi Hasil Prates dan Pascates Keterampilan Membaca Pemahaman pada Kelas Eksperimen dan Kelas Kontrol


Dalam penelitian ini untuk mengetahui data hasil keterampilan membaca pemahaman siswa dilakukan dengan memberikan tes kepada siswa pada kedua kelas. Keterampilan membaca pemahaman diukur berdasarkan 5 indikator, yaitu 1)menangkap informasi yang tersurat dalam wacana, 2) menemukan ide pokok dalam wacana, 3) menangkap makna tersirat dalam wacana, 4) menilai ide yang dipaparkan penulis di dalam wacana menurut pengetahuan dan pengalaman siswa, 5) menentukan sikap untuk menghargai gagasan yang tertuang dalam wacana.Data tersebut berupa skor pratesdan skor pascatesdari kelas eksperimen dan kelas kontrol.

Rata-rata nilai prates kelas eksperimen adalah 72,67,Nilai median sebesar 72,50 dan nilai modus sebesar 63 . Standard deviasi adalah 14,235 dan varians adalah 202,644, makin besar standard deviasi menunjukan data semakin bervariasi. Nilai minimum data adalah 51 dan nilai maksimum nya adalah 91 sehingga range $=$ nilai maksimum - nilai minimum $=91-51=40$.

Rata-rata nilai pascates kelas eksperimen adalah 87,47, Nilai median sebesar 89 dan nilai modus sebesar 94 . Standard deviasi adalah 8,729 dan varians adalah 76,189, makin besar standard deviasi menunjukan data semakin bervariasi. Nilai minimum data adalah 66 dan nilai maksimum nya adalah 100 sehingga range $=$ nilai maksimum - nilai minimum $=100-66=34$.

Sedangkan rata-rata nilai prates kelas kontrol adalah 72,10,Nilai median sebesar 72,50 dan nilai modus sebesar 80 . Standard deviasi adalah 12,047 dan varians adalah 145,128 makin besar standard deviasi menunjukan data semakin bervariasi. Nilai minimum data adalah 54 dan nilai maksimum nya adalah 94 sehingga range $=$ nilai maksimum - nilai minimum $=94-54=40$

Rata-rata nilai pascates kelas kontrol adalah 79,27 Nilai median sebesar 80 dan nilai modus sebesar 80 . Standard deviasi adalah 10,667 dan varians adalah 113,789makin besar standard deviasi menunjukan data semakin bervariasi. Nilai minimum data adalah 63 dan nilai maksimum nya adalah 100 sehingga range $=$ nilai maksimum - nilai minimum $=100$ $-63=37$.

Hasil skor pascatesketerampilan membaca pemahaman wacana siswa dikelompokkan atas tiga kategori, yaitu kategori tinggi, kategori sedang, dan kategori rendah. Rekapitulasi pengkategorian skor pascatesketerampilan membaca pemahaman wacana pada kelas eksperimen dan kelas kontrol dapat dilihat pada tabel di bawah ini.

\begin{tabular}{|l|c|c|}
\hline \multirow{2}{*}{$\begin{array}{c}\text { Kategori } \\
\text { Pengelompokan }\end{array}$} & \multicolumn{2}{c|}{ Jumlah siswa } \\
\cline { 2 - 3 } & Eksperimen & Kontrol \\
\hline Tinggi & 4 orang & 4 orang \\
\hline Sedang & 21 orang & 20 orang \\
\hline Rendah & 5 orang & 6 orang \\
\hline Jumlah & 30 orang & 30 orang \\
\hline
\end{tabular}

Berdasarkan tabel di atas, terlihat bahwa kelompok kategori tinggi keterampilan membaca pemahaman siswa kelas eksperimen adalah 4 orang, kategori sedang 21 orang, dan kategori rendah sebanyak 5 orang. Begitu juga dengan kelas kontrol, kategori tinggi keterampilan membaca pemahaman wacana siswa kelas kontrol sebanyak 6 orang, kategori sedang 20 orang, dan kategori rendah 4 orang. Hal ini menunjukkan bahwa keterampilan membaca pemahaman wacana siswa kelas eksperimen dan siswa kelas kontrol terbanyak berada pada kategori sedang.

Pada kelas eksperimen, sampel kelompok kategori tinggi dengan subjek no.30 prates mendapat skor 86 dengan interpretasi sangat baik. Pada pascates subjek tersebut mendapatkan skor 100 dengan interpretasi sangat baik. Terdapat peningkatan skor sebesar 14 yang menempatkan subjek tersebut termasuk ke dalam kategori tinggi dengan interpretasi sangat baik. Sampel kelompok kategori sedang dengan subjek no. 10 prates mendapatkan skor 60 dengan interpretasi 
sedang. Pada pascates subjek tersebut mendapatkan skor 86 dengan interpretasi sangatbaik. Terdapat peningkatan skor sebesar 26 yang menempatkan subjek tersebut ke dalam kategori sedang. Sampel kelompok kategori rendah dengan subjek no. 8 prates mendapatkan skor 51 dengan interpretasi kurang. Pada pascates subjek tersebut mendapatkan skor 66 dengan interpretasi sedang. Terdapat peningkatan skor sebesar 14 yang menempatkan subjek tersebut termasuk ke dalam kategori rendah.

Pada kelas kontrol, sampel kelompok kategori tinggi dengan subjek no.10 prates mendapat skor 86 dengan interpretasi sangat baik. Pada pascates subjek tersebut mendapatkan skor 94 dengan interpretasi sangat baik. Terdapat peningkatan skor sebesar 6 yang menempatkan subjek tersebut termasuk ke dalam kategori tinggi dengan interpretasi sangat baik. Sampel kelompok kategori sedang dengan subjek no. 14 prates mendapatkan skor 63 dengan interpretasi sedang. Pada pascates subjek tersebut mendapatkan skor 71 dengan interpretasi sedang. Terdapat peningkatan skor sebesar 8 yang menempatkan subjek tersebut ke dalam kategori sedang. Sampel kelompok kategori rendah dengan subjek no. 24 prates mendapatkan skor 54 dengan interpretasi kurang. Pada pascates subjek tersebut mendapatkan skor 63 dengan interpretasi sedang. Terdapat peningkatan skor sebesar 9 yang menempatkan subjek tersebut termasuk ke dalam kategori rendah.

Penemuan di lapangan terkait dengan jawaban tes keterampilan membaca pemahaman wacana siswa yang belajar melalui model pembelajaran CIRC dibandingkan dengan siswa yang tidak belajar melalui model pembelajaran CIRC dapat dilihat dari indikator yang dijadikan acuan dalam mengukur keterampilan membaca pemahaman wacana siswa.

\section{Menangkap Informasi yang Tersurat}

Indikator pertama tes keterampilan membaca pemahaman wacana siswa adalah menangkap informasi yang tersurat. Untuk mengukur indikator ini, soal yang diberikan pada siswa adalah soal uraian singkat.

Pembahasan hasil temuan jawaban siswa mencapai indikator menangkap informasi yang tersurat akan dijelaskan di bawah ini berdasarkan kelompok kategori tinggi, kategori sedang, dan kategori rendah dari kelas eksperimen dan kelas kontrol.

\section{a. Kelompok Kategori Tinggi}

Pada kelas eksperimen, siswa yang dapat menjawab semua soal dengan benar adalah 3 orang. Pada kelas kontrol, siswa yang dapat menjawab dengan benar semua soal adalah 4 orang.Artinya, model pembelajaran CIRC belum memberikan perbedaanpositif pada siswa untuk menjawab soal indikator menangkap informasi tersurat.

\section{b. Kelompok Kategori Sedang}

Pada kelas eksperimen, siswa menjawab benar semua soal indikator menangkap informasi tersuratadalah 6 orang. Pada kelas kontrol, siswa yang dapat menjawab dengan benar semua soal adalah 1 orang.Artinya, model pembelajaran CIRC memberikan perbedaan positif pada siswa kelompok kategori sedang kelas eksperimen untuk menjawab soal indikator menangkap informasi tersurat.

\section{c. Kelompok Kategori Rendah}

Pada kelas eksperimen, siswa yang menjawab benar semua soal adalah 2 orang sedangkan pada kelas kontrol tidak ada siswa yang menjawab benar semua soal.Artinya, model pembelajaran CIRC memberikan perbedaanpositif pada siswa untuk menjawab soal indikator menangkap informasi tersurat dalam wacana.

\section{Menemukan Ide Pokok Dalam Wacana}

Indikator kedua tes keterampilan membaca pemahaman wacana adalah menemukan ide pokok dalam wacana diukur dengan 
soal uraian singkat. Soal yang diberikan adalah sebanyak 3 butir soal.

\section{a. Kelompok Kategori Tinggi}

Pada kelas eksperimen, siswa yang dapat menjawab semua soal dengan benar adalah 4 orang. Pada kelas kontrol, siswa yang dapat menjawab dengan benar semua soal adalah 4 orang.Artinya, model pembelajaran CIRC memberikan perbedaan positif pada siswa untuk menjawab soal indikator menemukan ide pokok dalam wacana.

\section{b. Kelompok Kategori Sedang}

Pada kelas eksperimen, siswa menjawab benar semua soal indikator menemukan ide pokok dalam wacanaadalah 16 orang sedangkan pada kelas control, siswa yang menjawab benar semua soal indikator menemukan ide pokok dalam wacana adalah 10 orang.Artinya, model pembelajaran CIRC memberikan perbedaan positif pada siswa kelompok kategori sedang kelas eksperimen untuk menjawab soal indikator menemukan ide pokok dalam wacana.

\section{c. Kelompok Kategori Rendah}

Pada kelas eksperimen, siswa yang menjawab benar semua soal adalah 2 orang sedangkan pada kelas kontrol tidak ada siswa yang menjawab benar semua soal. Artinya, model pembelajaran CIRC memberikan perbedaan positif pada siswa untuk menjawab soal indikator menangkap informasi tersurat dalam wacana.

\section{Menangkap Makna Tersirat Dalam Wacana}

Indikator ketiga tes keterampilan membaca pemahaman adalah menangkap makna tersirat dalam wacana diukur dengan soal uraian singkat. Soal yang diberikan adalah sebanyak 2 butir soal.

\section{a. Kelompok Kategori Tinggi}

Pada kelas eksperimen, siswa yang dapat menjawab semua soal dengan benar adalah 4 orang. Pada kelas kontrol, siswa yang dapat menjawab dengan benar semua soal adalah 2 orang. Artinya, model pembelajaran CIRC memberikan perbedaan positif pada siswa untuk menjawab soal menangkap makna tersirat dalam wacana.

\section{b. Kelompok Kategori Sedang}

Pada kelas eksperimen, siswa menjawab benar semua soal indikator adalah 8 orang sedangkan pada kelas kontrol, siswa yang menjawab benar semua soal adalah 1 orang.Artinya, model pembelajaran CIRC memberikan perbedaan positif pada siswa kelompok kategori sedang kelas eksperimen untuk menjawab soal indikator menangkap makna tersirat dalam wacana.

\section{c. Kelompok Kategori Rendah}

Pada kelas eksperimen, siswa yang menjawab benar semua soal adalah 1 orang sedangkan pada kelas kontrol, tidak ada siswa yang menjawab benar semua soal. Artinya, model pembelajaran CIRC memberikan perbedaan positif pada siswa untuk menjawab soal indikator menangkap makna tersirat dalam wacana.

\section{Menilai Ide Yang Dipaparkan Penulis Di Dalam Wacana Menurut Pengetahuan Dan Pengalaman Siswa}

Indikator keempat tes keterampilan membaca pemahaman adalah menilai ide yang dipaparkan penulis di dalam wacana menurut pengetahuan dan pengalaman siswa diukur dengan soal uraian singkat. Soal yang diberikan adalah sebanyak 2 butir soal.

\section{a. Kelompok Kategori Tinggi}

Pada kelas eksperimen, siswa yang dapat menjawab semua soal dengan benar adalah 3 orang. Pada kelas kontrol, siswa yang dapat menjawab dengan benar semua soal adalah 2 orang. Artinya, model pembelajaran CIRC memberikan perbedaan positif pada siswa untuk menjawab soal indikatormenilai ide yang dipaparkan penulis di dalam wacana menurut pengetahuan dan pengalaman siswa.

\section{b. Kelompok Kategori Sedang}

Pada kelas eksperimen, siswa menjawab benar semua soal adalah 6 orang sedangkan pada kelas kontrol,siswa yang 
menjawab benar semua soal indikator adalah 2 orang.Artinya, model pembelajaran CIRC memberikan perbedaan positif pada siswa kelompok kategori sedang kelas eksperimen untuk menjawab soal indikator menilai ide yang dipaparkan penulis di dalam wacana menurut pengetahuan dan pengalaman siswa.

\section{c. Kelompok Kategori Rendah}

Pada kelas eksperimen, tidak siswa yang menjawab benar semua soal sedangkan pada kelas kontrol, tidak ada siswa yang menjawab benar semua soal. Artinya, model pembelajaran CIRC belum memberikan perbedaan positif pada siswa untuk menjawab soal indikator menilai ide yang dipaparkan penulis di dalam wacana menurut pengetahuan dan pengalaman siswa.

\section{Menentukan Sikap Untuk Menghargai Gagasan Yang Tertuang Dalam Wacana}

Indikator kelima tes keterampilan membaca pemahahaman adalah menilai menentukan sikap untuk menghargai gagasan yang tertuang dalam wacana diukur dengan soal uraian singkat. Soal yang diberikan adalah sebanyak 2 butir soal.

\section{a. Kelompok Kategori Tinggi}

Pada kelas eksperimen, siswa yang dapat menjawab semua soal dengan benar adalah 4 orang. Pada kelas kontrol, siswa yang dapat menjawab dengan benar semua soal adalah 4 orang.Artinya, model pembelajaran CIRC memberikan perbedaan positif pada siswa untuk menjawab soal indikatormenentukan sikap untuk menghargai gagasan yang tertuang dalam wacana.

\section{b. Kelompok Kategori Sedang}

Pada kelas eksperimen, siswa menjawab benar semua soal adalah 12 orang sedangkan pada kelas kontrol, siswa yang menjawab benar semua soal adalah 1 orang.Artinya, model pembelajaran CIRC memberikan perbedaan positif pada siswa kelompok kategori sedang kelas eksperimen untuk menjawab soal indikator menentukan sikap untuk menghargai gagasan yang tertuang dalam wacana.

\section{c. Kelompok Kategori Rendah}

Pada kelas eksperimen,siswa yang menjawab benar semua soal adalah 1 orang sedangkan pada kelas kontrol, tidak ada siswa yang menjawab benar semua soal.Artinya, model pembelajaran CIRC memberikan perbedaan positif pada siswa

\begin{tabular}{|c|c|c|c|}
\hline $\begin{array}{c}\text { Mann- } \\
\text { Whitney U }\end{array}$ & $\mathbf{Z}$ & $\begin{array}{c}\text { Asymp. } \\
\text { Sig. (2- } \\
\text { tailed) }\end{array}$ & Kesimpulan \\
\hline 436,000 & $-0,208$ & 0,836 & $\begin{array}{c}\text { Tidak } \\
\text { Terdapat } \\
\text { perbedaan }\end{array}$ \\
\hline
\end{tabular}

untuk menjawab soal indikator menentukan sikap untuk menghargai gagasan yang tertuang dalam wacana.

\section{B. Uji Prasyarat Data Keterampilan Membaca Pemahaman}

Hasil uji normalitas data tes keterampilan membaca pemahaman dapat dilihat pada tabel berikut ini.

\begin{tabular}{|l|c|c|}
\hline \multicolumn{1}{|c|}{ Data } & Kelas & Kesimpulan \\
\hline Skor Prates & \multirow{2}{*}{ Eksperimen } & Tidak Normal \\
Skor Pascates & & Tidak Normal \\
\hline Skor Prates & \multirow{2}{*}{ Kontrol } & Normal \\
\cline { 1 - 1 } Skor Pascates & & Normal \\
\hline
\end{tabular}

Berdasarkantabel di atas, dapat diketahui bahwa hasil uji normalitas keterampilan membaca pemahahamn kelas eksperimen pada skor pratesadalah 0,004 dan pascates adalah 0,042. Maka nilai signifikansi (Sig) prates maupun pascates lebih kecil dari 0,05, sehingga kedua data dinyatakan tidaknormal. Hasil uji normalitas data keterampilan membaca pemahaman kelas kontrol pada skor pratesadalah 0,174 dan pascates adalah 0,197 . Maka nilai signifikansi (Sig) prates maupun pascates lebih besar dari 0,05, sehingga kedua data dinyatakan normal.

Melalui data tersebut, maka untuk uji komparasi prates maupun pascatesketerampilan membaca pemahaman menggunakan uji Mann Whitney. Hal tersebut dikarenakan data 
kelas eksperimen tidak berdistribusi normal walaupun kelas kontrol berdistribusi normal sehingga data tersebut tidak perlu dilakukan uji homogenitas.

\section{Uji Perbedaan Rerata Keterampilan Membaca Pemahaman}

Uji Mann-Whitney dilakukan karena dari data yang telah diolah didapati data yang tidak berdistribusi normal sehingga uji ini dilakukan sebagai penggati uji-t.

Berikut ini hasil mann-whitney data pratesketerampilan membaca pemahaman siswa pada kelas eksperimen dan kelas kontrol:

Dapat dilihat pada tabel di atas bahwa hasil uji Mann-Whitney diperoleh nilai sig(2-tailed) $=0,836$ yang artinya nilai sig(2-tailed) $0,836>0,05$. sehingga dapat dinyatakan bahwa tidak ada perbedaan kemampuan awal keterampilan membaca pemahaman siswa pada kelas eksperimen dengan siswa kelas kontrol. Hasil uji Mann-Whitney data pratesketerampilan membaca pemahaman siswa antara siswa kelas eksperimen dengan kelas kontrol, dinyatakan bahwa data tersebut tidak terdapat perbedaan sehingga kemampuan awal siswa dalam keterampilan pemahaman bacaan antara kelas yang menggunakan model pembelajaran CIRC dengan metode pembelajaran konvensional adalah sama.

Berikut ini hasil mann-whitneydata pascatesketerampilan membaca pemahaman siswapada kelas eksperimen dan kelas kontrol:

\begin{tabular}{|c|c|c|c|}
\hline $\begin{array}{c}\text { Mann- } \\
\text { Whitney U }\end{array}$ & Z & $\begin{array}{c}\text { Asymp. } \\
\text { Sig. (2- } \\
\text { tailed) }\end{array}$ & Kesimpulan \\
\hline 241,000 & -3.104 & 0,002 & $\begin{array}{c}\text { Terdapat } \\
\text { Perbedaan }\end{array}$ \\
\hline
\end{tabular}

Dapat dilihat pada tabel di atas bahwa hasil uji Mann-Whitney diperoleh nilai sig $(2$-tailed $)=0,002$ yang artinya nilai sig (2-tailed) $0,002<0,05$. Sehingga dapat dinyatakan bahwa terdapat perbedaan keterampilan membaca pemahaman siswa antara siswa kelas eksperimen dengan kelas kontrol.Pada hasil uji Mann-Whitney data pascatesketerampilan membaca pemahaman antara siswa kelas eksperimen dengan kelas kontrol dinyatakan terdapat perbedaan yang signifikan sehingga membuktikan bahwa model pembelajaran CIRC memberikan pengaruh yang signifikan terhadap keterampilan membaca pemahaman siswa.

\section{Uji N-Gain}

Pada uji n-gain kali ini yakni untuk mencari selisih antara nilai pascates dan prates berdasarkan atas skor ideal sehingga dapat menunjukkan besarnya kualitas peningkatan hasil tes yang telah dilakukan. Data yang diuji yaitu hasil prates dan pascates kedua kelas mengenai dua variabel dependen.

Hasil uji n-gain dapat di lihat pada tabel berikut ini:

\begin{tabular}{|c|l|c|c|l|}
\hline \multirow{2}{*}{ Kelas } & \multirow{2}{*}{$\begin{array}{c}\text { Keterampilan } \\
\text { Membaca }\end{array}$} & \multicolumn{2}{|c|}{ Skor } & \multirow{2}{*}{ Kriteria } \\
\cline { 3 - 4 } & Pemahaman & $\begin{array}{c}\text { Rata- } \\
\text { rata }\end{array}$ & $\begin{array}{c}\text { N- } \\
\text { gain }\end{array}$ & \\
\hline \multirow{2}{*}{ Eksperimen } & Pratest & 72,67 & \multirow{2}{*}{0,58} & \multirow{2}{*}{ Sedang } \\
\cline { 2 - 3 } & Pascatest & 87,53 & & \\
\hline \multirow{2}{*}{ Kontrol } & Pratest & 72,19 & \multirow{2}{*}{0,30} & Rendah \\
\cline { 2 - 3 } & Pascatest & 79,26 & & \\
\hline
\end{tabular}

Berdasarkan tabel di atas dapat di interpretasikan bahwa skor rata-rata pratesketerampilan membaca pemahaman pada kelas eksperimen sebesar 72,67 dan hasil pascatessebesar 87,53. Dari data tersebut diperoleh n-gain sebesar 0,58. Maka n-gain pada kelas eksperimen termasuk ke dalam kriteria sedang. Pada kelas kontrol dapat dilihat bahwa skor rata-rata pratest keterampilan membaca pemahaman sebesar 72,19 dan skor pascatessebesar 79,26. Sehingga diperoleh n-gain sebesar 0,30. Maka dapat disimpulkan bahwa n-gain pada kelas kontrol termasuk ke dalam kriteria rendah.

\section{Pembahasan}

Berdasarkan hasil analisis penelitian yang telah dilakukan, diperoleh data ratarata prates keterampilan membaca pemahaman wacana siswa pada kelas eksperimen yaitu 72,67 dengan rata-rata pascates sebesar 87,47. Sedangkan nilai 
rata-rata prates keterampilan membaca pemahaman wacana pada kelas kontrol yaitu sebesar 72,10 dengan nilai rata-rata pascates yaitu 79,27. Melalui data hasil prates dan pascates tersebut dapat diamati bahwa ada peningkatan nilai prates kenilai pascates dari kelas eksperimen maupun kelas kontrol.

Untuk lebih mengetahui seberapa besar peningkatan dan perbedaannya maka dapat diamati pada nilai uji gain. Pada kelas eksperimen skor $\mathrm{N}$-gain yaitu 0,58 dan apabila dilihat pada kriteria gain hasil tersebut menunjukkan kriteria "sedang". Sedangkan pada kelas kontrol memperoleh skor $\mathrm{N}$-gain sebesar 0,30, nilai tersebut masuk pada kriteria "rendah". Hal tersebut dapat membuktikan bahwa pembelajaran dengan menggunakan model pembelajaran CIRCdapat meningkatkan keterampilan membaca pemahaman wacana siswa.

Selain itu, pembuktian bahwa model pembelajaran CIRC jika dibandingkan dengan pembelajaran konvensional yaitu dapat terlihat pada hasil uji MannWhitney. Uji ini dilakukan karena pada pengujian normalitas data ternyata terdapat data yang tidak normal sehingga uji ini dilakukan. Dalam uji tersebut menginterpretasikan data prateskelas eksperimen dan kelas kontrol terbukti tidak terdapat perbedaan. Sehingga menunjukkan bahwa tidak ada perbedaan kemampuan awal siswa pada kelas eksperimen maupun kelas kontrol. Hal tersebut membuktikan bahwa hasil prates yang baik. Pernyataan tersebut didukung oleh Sugiyono (2013, hlm.113) yang menjelaskan bahwa hasil prates yang baik bila nilai kelompok eksperimen tidak berbeda secara signifikan dengan kelompok kontrol. Sehingga menunjukkan bahwa tidak ada perbedaan kemampuan awal siswa pada kelas eksperimen maupun kelas control.

Setelah itu dilakukan uji MannWhitney pada data pascates antara kelas eksperimen dengan kelas kontrol. Pada hasil uji Mann-Whitney nilai Sig (2-tailed) menunjukkan angka positif. Hal tersebut terbukti bahwa pembelajaran dengan menggunakan model CIRC pada kelas eksperimen lebih meningkatkan keterampilan membaca pemahaman wacana siswa jika dibandingkan dengan kelas kontrol yang menggunakan pembelajaran konvensional. Hal tersebut sejalan sesuai dengan penelitian yang telah dibuktikan oleh Madden, Stevens, dan Slavin (Sharan, 2014, hlm.37) yang menyatakan bahwa secara keseluruhan , pengaruh program CIRC pada pencapaian siswa cukup positif. Kelas-kelas CIRC memperoleh nilai rata-rata $30 \%$ sampai $36 \%$ lebih tinggi dalam pemahaman bacaan. Dengan demikian, pengaruh CIRC sama-sama dirasakan siswa pada semua tingkat kemampuan mulai dari yang rendah, sedang dan tinggi.

Berdasarkan pemaparan hasil pemaparan tersebut, sesuai dengan yang dikemukakan oleh Abidin (2010, hlm.150) bahwa metode CIRC pada dasarnya bertujuan untuk meningkatkan kemampuan siswa dalam memahami isi bacaan. CIRC membantu guru menyajikan pembelajaran memahami isi bacaan secara kooperatif dan kolaboratif sehingga hasil belajar siswa menjadi lebih baik. Abidin (2014, hlm. 241) mengatakan bahwa pembelajaran kooperatif merupakan sistem pembelajaran yang memberikan kesempatan kepada anak didik untuk bekerja sama dengan sesama siswa untuk menyelesaikan tugas-tugas terstruktur. Hal tersebut sejalan dengan yang disampaikan Hiebert (dalam Slavin, 2010, hlm. 201) bahwa sebuah fitur yang bersifat hampir selalu universal dari pengajaran membaca adalah penggunaan kelompok membaca yang terdiri atas para siswa dengan tingkat kinerja yang sama. Dengan demikian, keberhasilan siswa untuk memahami bahan bacaan dalam pembelajaran kooperatif tidak hanya berdasarkan kemampuan dirinya tetapi ada andil dari anggota kelompoknya dan kelompok lain selama pembelajaran. 


\section{Simpulan dan Saran}

Terdapat perbedaan keterampilan membaca pemahaman antara siswa kelas eksperimen yang menerapkan model CIRC dengan kelas kontol yang menerapkan pembelajaran konvensional serta pada uji n-gain menunjukkan, siswa yang memperoleh pembelajaran model CIRC memiliki peningkatan keterampilan membaca pemahaman yang lebih tinggi dibanding siswa yang memperoleh pembelajaran konvensional. Dengan demikian dapat diketahui bahwa keterampilan membaca pemahaman siswa pada kelas eksperimen dengan model CIRC lebih baik daripada penerapan pembelajaran konvensional di kelas kontrol.

Rekomendasi yang dapat dijadikan bahan pertimbangan dalam upaya meningkatkan kualitas pembelajaran.

1. Bagi Peneliti Selanjutnya

Hasil penelitian ini semoga menjadi bahan perbandingan untuk penelitian selanjutnya berkaitan dengan penerapan model CIRC. Dengan demikian model CIRC dapat digunakan secara efektif baik dari segi proses maupun pembelajarannya sehingga pada penelitian selanjutnya dapat memperoleh hasil yang positif untuk meningkatkan keterampilan membaca pemahaman. Diharapkan untuk mengkaji kembali pengaruh penerapanmodel pembelajaran CIRC terhadap peningkatkan keterampilan berbahasa lain atau pada mata pelajaran lain, sehingga tidak terbatas hanya pada keterampilan membaca dan menulis saja.

\section{Bagi Guru}

Model CIRC dapat dijadikan alternatif model pembelajaran berbahasa untuk meningkatkan kualitas pendidikan terutama keterampilan membaca pemahaman. Namun, dalam hal ini guru harus memperhatikan: bahan bacaan, pengelolaan kelas dan waktu pembelajaran.

3. Bagi Kepala Sekolah
Diharapkan kepala sekolah, sebagai pimpinan di sekolah memberikan motivasi serta arahan kepada para guru untuk selalu meningkatkan kualitas pembelajaran dengan cara mengembangkan modelmodel pembelajaran yang ada. Salah satunya yakni model CIRC untuk diterapkan dalam pembelajaran bahasa Indonesia.

4. Bagi Para Pembuat Kebijakan

Diharapkan untuk memberikan pelatihan bagi para guru agar senantiasa menggunakan model pembelajaran yang inovatif kepada siswa.

\section{Daftar Pustaka}

Abidin, Y. (2010). Strategi membaca teori dan pembelajarannya. Bandung: Rizqi Press.

Abidin, Y. (2014).Desain sistem pembelajaran dalam konteks kurikulum 2013. Bandung: Refika aditama.

BSNP. (2006). Panduan penyusunan kurikulum tingkat satuan pendidikan. Jakarta: Depdikna.

Hosnan. (2014). Pendekatan saintifik dan kontekstual dalam pembelajaran abad 21. Bogor: Ghalia Indonesia.

Huda, M. (2011). Pembelajaran kooperatif, metode, teknik, struktur dan model penelitian. Yogyakarta: Pustaka pelajar.

Lie, A. (2010). Mempraktikkan cooperative learning di ruangruang kelas. Jakarta: Grasindo.

Linse, C. T. (2005). Practical english language teaching young learners. New York: McGraw Hill.

OECD. (2010). PISA 2009 results: what students know and can do volume I. Canada: OECD. 
Rahim, F. (2005). Pengajaran membaca di sekolah dasar. Jakarta: Bumi Aksara.

Sugiyono. (2013). Metode penelitian Tarigan, H. G. (2013). Membaca sebagai suatu keterampilan berbahasa. Bandung:

Angkasa pendidikan kuantitatif, kualitatif, dan $r \& d$. Bandung: Alfabeta. 